\title{
The Anti-Angiogenic Properties of Morinda citrifolia L. (Mengkudu) Leaves using Chicken Chorioallantoic Membrane (CAM) Assay
}

\author{
Zulhabri Othman ${ }^{1,2 *}$, Hamimi Rasyiqah Hassan Khalep', Azrina Zainal Abidin', Halijah Hassan', Santosh Fattepur ${ }^{3}$
}

\section{Zulhabri Othman ${ }^{1,2^{*}}$, Hamimi Rasyiqah Hassan Khalep ${ }^{1}$, Azrina Zainal Abidin', Halijah Hassan', Santosh Fattepur ${ }^{3}$}

\section{'Department of Diagnostic and Allied Health Science, Faculty of Health and Life Sciences, Management and Science University, 40100 Shah Alam, Selangor, MALAYSIA. \\ ${ }^{2} S$ chool of Graduate Studies, Post-Graduate Centre, Management and Science University, MALAYSIA. ${ }^{3}$ School of Pharmacy, Management and Science University, 40100 Shah Alam, Selangor, MALAYSIA.}

\section{Correspondence}

Dr. Zulhabri Othman

Department of Diagnostic and Allied Health Science, Faculty of Health and Life Sciences, Management and Science University, 40100 Shah Alam, Selangor, MALAYSIA.

Phone no : +60-03-5521 6454

E-mail: zulhabri_othman@yahoo.com

History

- Submission Date: 05-11-2018;

- Review completed: 20-11-2018;

- Accepted Date: 10-12-2018

DOI : 10.5530/pj.2019.1.3

Article Available online

http://www.phcogj.com/v11/i1

\section{Copyright}

(C) 2019 Phcog.Net. This is an openaccess article distributed under the terms of the Creative Commons Attribution 4.0 International license.

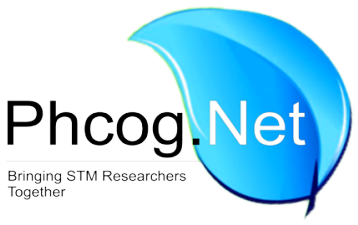

\begin{abstract}
Background: Anti-angiogenesis or inhibition of blood vessel formation is the best way to prevent the growth and metastasis of tumors. The use Morinda citrifolis L. extracts have been reported to exhibit a broad range of therapeutic effects, including antibacterial and antitumor. Objective: This study aims to investigate the anti-angiogenic properties of Morinda citrifolia L. leaves extracts using Chicken Chorioallantoic Membrane (CAM) assay. Materials and Methods: The Fertile White Leghorn eggs were divided into five groups which were control, Bevacizumab drug and treatment groups with $25 \%, 50 \%$ and $75 \%$ of Morinda citrifolia L. leaves extracts respectively. The reduction of the blood vessel was counted after $12 \mathrm{~h}$ and $24 \mathrm{~h}$ post-treatment. Results: Analysis have shown significant differences $(P<0.05)$ in the reduction of the blood vessel between each group at $24 \mathrm{~h}$ post-treatment. The group with $75 \%$ extracts showed $37.1 \%$ reductions of blood vessel compared to groups $50 \%$ and $25 \%$ extracts which showed $4 \%$ and $12.8 \%$ respectively. The phytochemical screening has showed that Morinda citrifolia L. leaves extracts was positive for flavonoid, phenols and phytosterols. Conclusion: Morinda citrifolia L. leaves extracts consist of the phytochemical compounds that have the ability to inhibit the angiogenesis.

Key words: Anti-angiogenesis, Morinda citrifolia L. leaves, Phytochemical, White Leghorn eggs, Chicken Chorioallantoic Membrane (CAM) assay.
\end{abstract}

\section{INTRODUCTION}

Cancer has the ability to spread to adjacent or distant organs, which makes it life threatening. Tumor cells can penetrate blood or lymphatic vessels, circulate through the blood system and then proliferate at another site which is called metastasis. ${ }^{1}$ Angiogenesis is a multistep process leading to the formation of new capillaries emerging from pre-existing blood vessel systems. Recruitment of new blood vessels plays an important role in tumor survival and growth. ${ }^{2}$ Abnormal blood vessel growth, either excessive or insufficient, is now recognized as a "common denominator" underlying many deadly and debilitating conditions, including cancer. $^{3}$

Morinda citrifolia L. has been heavily promoted for a wide range of uses, including arthritis, atherosclerosis, burns and cancer. ${ }^{4}$ Studies have shown that many of these bioactive components possess anti-inflammatory, anti-atherosclerotic, anti-tumor, anti-mutagenic, anticarcinogenic, anti-bacterial and anti-viral activities. Several local plants extracts have shown to have phytochemical compounds such as tannins, alkaloid, steroids, flavonoids and saponins that shown to have anti-bacteria activity especially towards Staphylococcus aureus. ${ }^{5-7}$ Morinda citrifolia L. extracts also have shown to decreased inflammation, oxidative stress, cortisol and hexose-6-phosphate dehydrogenase (H6PD) expressions in cancer cells. ${ }^{8}$ The previous phytochemical studies reported that Noni's leaves contain a variety of phytochemical constituents such as terpenoids, phytosterol, flavonoid glycosides and anthraquinone..$^{9,10}$

This study aims to investigate the phytochemical properties and anti-angiogenic activity in Morinda citrifolia L. leaves extract in chicken chorioallantoic membrane (CAM) assay. Besides the study would emphasize on the identification of the phytochemical compound of Morinda citrifolia L. leaves extracts. Furthermore, to examine the anti-angiogenic properties of Morinda citrifolia L. leaves extraction using CAM assay and thus to compare the effect of Morinda citrifolia L. leaves extraction with Bevazicumab drug.

\section{MATERIALS AND METHODS}

\section{Collection of Plant Material}

The samples were collected locally at Kampung Kenangan Puchong and the identification species was at Forest Research of Institute Malaysia (FRIM), 
Kepong, Selangor, Malaysia. The specimen identification of Morinda citrifolia L. leaves was obtained from the Herbarium of Forest Research Institute Malaysia (FRIM).

\section{Preparation of Plant Extracts}

The samples were wash, cut into small pieces and dried in an oven at $37^{\circ} \mathrm{C}$ for $72 \mathrm{~h}$ and then ground into a fine powder with electrical grinder. $200 \mathrm{~g}$ of Morinda citrifolia L. powder was soaked into 95\% methanol for $24 \mathrm{~h}$ and filtered with Whatman no. 1 filtered paper and concentrated via rotary evaporator.

\section{Phytochemical Screening}

The Morinda citrifolia L. leaves extracts was then proceeding to phytochemical screening for flavanoid, phenols and phytosterol.

\section{Flavanoids}

The lead acetate test was used to determine the presence of flavanoids in a given sample. Dried samples $(5 \mathrm{mg}$ ) were mixed with a few drops of lead acetate solution. The formation of yellow colour precipitate indicates the presence of flavanoids. ${ }^{11}$

\section{Phenols}

The ferric chloride test was used to determine the presence or absence of phenols in a given sample. The dried sample $(5 \mathrm{mg})$ were added with 3-4 drops of ferric chloride solution. The formation of bluish black colour indicates the presences of phenols. ${ }^{11}$

\section{Phytosterols}

Salkowski's test was used to determine the presence or absence of phytosterol (plant sterol) in a given sample. Extracts $(5 \mathrm{mg})$ were mixed with $2 \mathrm{ml}$ of chloroform and filtered. The filtrates were added with few drops of concentrated sulphuric acid, shaken and allowed to stand. Appearance of golden brown colour indicates the presences of phytosterols. ${ }^{11}$

\section{Ex-ovo Chicken Chorioallantoic Membrane Assay (CAM)}

The White Leghorn eggs were incubated for three days at $40^{\circ} \mathrm{C}$ and $72 \pm 2 \%$ of relative humidity. On the third day, the eggs were cracked and the eggs content wsa transferred to the Petri dish followed with incubation for another three days. All the eggs were divided into five groups (control, Bevacizumab drug, treatment groups with 25\%, 50\% and 75\% extracts). Each group was done triplicate.

The extracts were diluted with $100 \mathrm{ml}$ of distilled water and $100 \mu \mathrm{l}$ of DMSO. Two pieces of Whatman no. 1 filtered papers with the size of $5 \mathrm{~mm}$ were put on the top of a fine blood vessel. Each filtered paper was added with extracts and PBS (phosphate buffer saline). PBS function was to moist the embryo and avoid it from dry. To maintain the survival of the embryo, PBS were applied every 4-5 times daily since day 6. The extracts were added on the day 6 . The image of the blood vessel was captured using camera after $12 \mathrm{~h}$ and $24 \mathrm{~h}$ post-treatment.

\section{Data and Sample Analysis}

The data was analyzed for the statistical image of identification and also the comparison of Ex-ovo. Chorioallantoic Membrane (CAM) Assay. The results of CAM assay were recorded and analyzed with one-way ANOVA (Analysis of Variance) using SPSS ${ }^{\mathrm{m}}$ (Statistical Package for Social Science) version 20 . The data were collected at two different time points which were at $12 \mathrm{~h}$ and $24 \mathrm{~h}$ post-treatment. The significance reduction of the blood vessel reported with $p<0.05$.

\section{RESULTS}

\section{Phytochemical Screening}

The pytochemical screening shows positives, indicates for the presence of flavanoids, phenols and phytosterols (Table 1) in the Morinda
Table 1: Phytochemical screening of flavonoid, phenols, phytosterols shows positive results for the Morinda citrifolia L. extract.

\begin{tabular}{cc}
\hline Phytochemical test & Results \\
\hline Flavonoids & + \\
Phenols & + \\
Phytosterols & + \\
\hline
\end{tabular}

citrifolia L. extracts. For flavonoid shows the appearance of yellow colour, meanwhile for phenols shows the formation of bluish black colour and for phytosterols shows the appearances of golden brown or yellow colour. The phytochemical screening of Morinda citrifolia L. leaves extract shows the presences of all main phytochemical compounds such as flavanoid, phenols and phytosterols.

\section{The Reduction of Blood Vessel}

The blood vessel has shown reduction with different concentrations of Morinda citrifolia L. leaves extraction (25\%, 50\% and 75\%) after $12 \mathrm{~h}$ and 24 h post-treatment on Ex-ovo chicken chorioallantoic membrane assay (CAM) (Figure 1). Results have shown significant differences $(P<0.05)$ in the reduction of the blood vessel between each group at 24 h posttreatment. At $75 \%$ extraction, after $12 \mathrm{~h}$ the blood vessel showed prevalent reduction to about $\pm 21.7 \%$ and after $24 \mathrm{~h}$ the reduction of the blood vessel reduces to $\pm 37.1 \%$. Meanwhile, at $50 \%$ extraction, $12 \mathrm{~h}$ have showed that reduction of the blood vessel increasingly reduce to $\pm 9.5 \%$ and $24 \mathrm{~h}$ to $\pm 12.8 \%$. However, at $25 \%$ extraction, for $12 \mathrm{~h}$ only a few reductions occur about $\pm 2 \%$ and $24 \mathrm{~h}$ about $\pm 4 \%$. For group with Bevacizumab drugs after $12 \mathrm{~h}$ the reduction of blood vessel reduces greatly compared to other extractions. It reduced about $\pm 38.8 \%$ and after $24 \mathrm{~h}$ the blood vessel reduces to $\pm 49.2 \%$ (Figure 2 ). The results of control groups for $12 \mathrm{~h}$ and $24 \mathrm{~h}$ do not show any reduction of the blood vessel.

The overall phase shows the results of the reduction of the blood vessel of Morinda citrifolia L. leaves extract after $12 \mathrm{~h}$ and $24 \mathrm{~h}$. There were significant differences on the percentages of blood vessel reduction between control group and with treatment groups. For the control group, there was no reduction of blood vessel occur, meanwhile for the lowest percentage was $25 \%$ extraction about $2 \%$ reductions and $4 \%$ reduction after $12 \mathrm{~h}$ and $24 \mathrm{~h}$ respectively. However, the highest percentage of the reduction was Bevacizumab drugs about $39 \%$ and $49 \%$ after $12 \mathrm{~h}$ and $24 \mathrm{~h}$ respectively.

The overall phase shows the result of the reduction of blood vessel with Morinda citrifolia L. leaves extract treatment after $24 \mathrm{~h}$. The bar chart was performed the reduction of blood vessel from the baseline $12 \mathrm{~h}$. The control doesn't show any reduction of blood vessel. Somehow, 25\% extraction shows reduction to 144 of blood vessel and was the lowest reduction after $24 \mathrm{~h}$. Meanwhile, the greater reduction of blood vessel was shows at $50 \%$ extraction compared to $25 \%$ extraction. On the other hand, at $75 \%$ extraction the blood vessel reduces to 95 blood vessels. However, for Bevacizumab drugs the blood vessel shows increasingly reduces to 77 blood vessels.

The overall phase shows that, there was a significant reduction of the blood vessel in different concentration after $12 \mathrm{~h}$ and $24 \mathrm{~h}$. In this direction, the plant is being actively explored as a source of new chemical substances that can inhibit angiogenesis. Independent of this effect in this study, it is clearly elucidated that anti-angiogenic activity of Morinda citrifolia L. leaves extract by performing ex-ovo anti-angiogenesis assay. It has been observed that Morinda citrifolia L. significantly inhibits the development of capillary networks in CAM. 


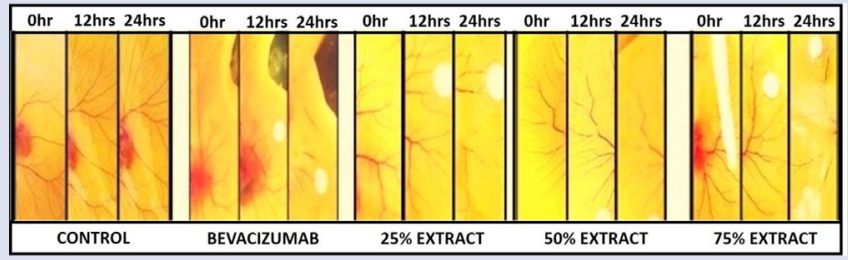

Figure 1: The reduction of the blood vessel with different concentrations of Morinda citrifolia L. leaves extraction (25\%,50\% and $75 \%$ ) after $12 \mathrm{~h}$ and $24 \mathrm{~h}$ post-treatment on Ex-ovo chicken chorioallantoic membrane assay (CAM).

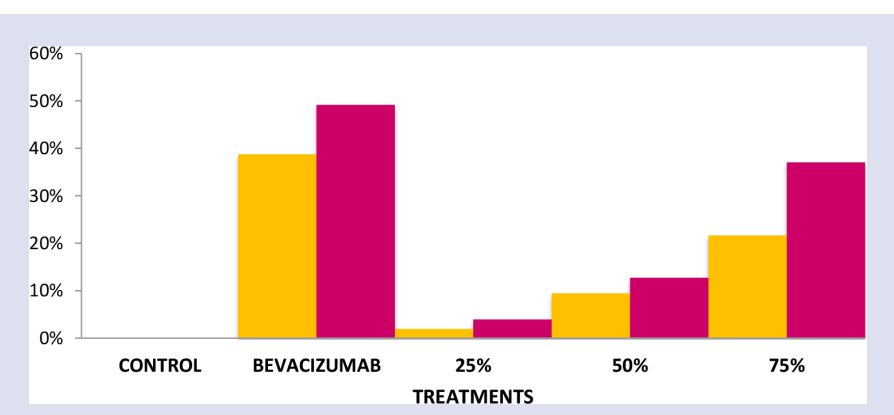

Figure 2: Percentage of the reduction of blood vessel. The higher percentage of blood vessel reduction was at $75 \%$ extracts of Morinda citrifolia L. compared to $50 \%$ and $25 \%$ extracts.

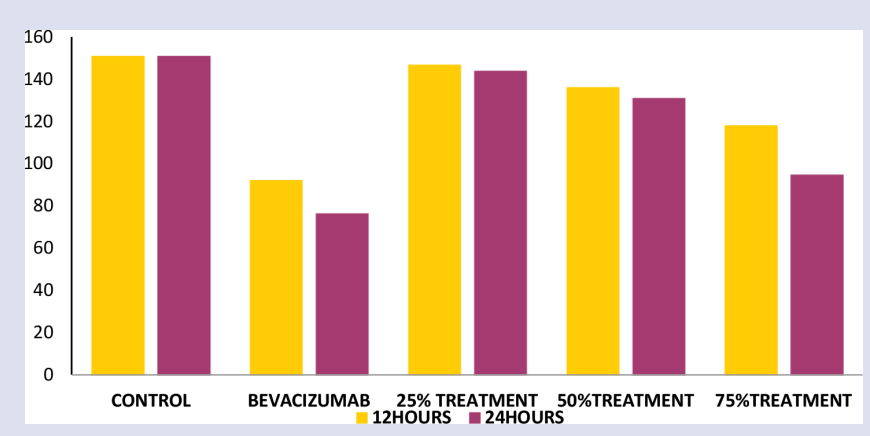

Figure 3: The comparison reduction of blood vessel after $12 \mathrm{~h}$ and $24 \mathrm{~h}$. For both $12 \mathrm{~h}$ and $24 \mathrm{~h} \mathrm{75 \%} \mathrm{extracts} \mathrm{of} \mathrm{Morinda} \mathrm{citrifolia} \mathrm{L.} \mathrm{shows} \mathrm{the}$ higher reduction of blood vessels compared to $50 \%$ and $25 \%$ extracts groups.

\section{Comparison Reduction of Blood Vessel between $12 \mathrm{~h}$ and $24 \mathrm{~h}$}

Assay with $75 \%$ extracts shows the highest reduction in the blood vessel formation after $24 \mathrm{~h}$ compared to $25 \%$ and $50 \%$ extracts groups (Figure 3 ). Thus, the $75 \%$ extracts shows decreasing numbers of blood vessel almost likely as Bevacizumab drug. Control group didn't show any reduction of the blood vessels.

\section{DISCUSSION}

A previous study by Saad et al. has suggested that Morinda citrifolia L. serve as a potent source of natural anti-oxidant and exhibit high of flavonoid, tannins and anthraquinones. ${ }^{12}$ Flavanoid and phenols are antioxidants compound which have role in cancer prevention. ${ }^{13}$ Mean- while, phytosterol has shown to inhibit angiogenesis. ${ }^{14}$ Morinda citrifolia L. extracts have shown to have a strong correlation between carotenoids and ascorbic acid, tannin, flavonoids and phenol. The genotypes showed wide range of antioxidant capacity which showed positive correlation with carotenoids, flavonoids and $\mathrm{Cu}, \mathrm{Mn}$ and $\mathrm{Mg} .{ }^{15}$ Study by Adnan et al. on photophysical properties of five natural anthraquinone as one of active compound from Morinda citrifolia L. extracts that may have medicinal value. ${ }^{16}$

This study suggests that Morinda citrifolia L. leaves extract at $75 \%$, strongly exhibit the anti-angiogenic activity. This study showed that the concentration of $75 \%$ extraction able to inhibit the formation of blood vessel, were more prominent compared to the concentration of $25 \%$ extraction after $12 \mathrm{~h}$ and $24 \mathrm{~h}$ of the extraction after treatment. These finding have in agreement with a report by Beh et al. that Morinda citrofolia. L extracts possess anti-angiogenic activity using CAM assay. ${ }^{17}$ In addition, it also has almost same ability to inhibit the blood vessel like Bevacizumab drugs. A previous study by Piaru et al. has showed that Morinda citrifolia L. oil have a tendency to reduce the growth of the blood vessel in anti-angiogenic effect using ex-vivo on rat aortic rings. ${ }^{18}$ Thus, it may have a potential to be useful deactivator of numerous serious disease characterized by angiogenesis. The virgin coconut oil has shown to possesses anti-atherosclerotic activity by decreases in atherogenic index and improve lipid profile while increase HDL level in rats. ${ }^{19}$

\section{CONCLUSION}

Morinda citrifolia L. leaves extracts have shown to contain phytochemical compounds and has the ability to inhibit the formation or growth of blood vessel. This study shows that the use of Morinda citrifolia L. leaves extract has a potential of anti-angiogenesis properties. The average branch points or blood vessel in the White Leghorn eggs using CAM assay was decreased with higher treatment of Morinda citrifolia L. leaves extract. The study has been concluded that Morinda citrifolia L. leaves extract has promising anti-angiogenic properties and a possible source of chemotherapeutic agent against cancer.

\section{ACKNOWLEDGEMENT}

The authors would like to thank to MSU for supporting this research. This study is funded by MSU Seed Grant SG-168-0613-HS.

\section{CONFLICT OF INTEREST}

The authors declare no conflict of interest.

\section{REFERENCES}

1. Folkman J. Tumor angiogenesis therapeutic implications. New England Journal of Medicine. 2006;285(21):1182-6

2. Jaywant J, Anuya M, Aruna K. Antiangiogenic properties of Boerhaavia diffusa extracts in chick chorioallantoic membrane (CAM). International Journal of Drug Development and Research. 2011;3(4):307-17.

3. Angio.org [homepage of internet] Massachussetts. Angiogenesis Foundation. What is Angiogenesis?. [updated 2017; cited 2018 October 15]. Available from: http://www.angio.org/about-angiogenesis

4. McClatchey W. From the Polynesian healers to health food stores; changing perspectives of Morinda citrifolia (Rubiaceae). Integrated Cancer Therapy. 2002;1(2):110-20.

5. Saad R, Appalasamy L, Khan J, Kazi H, Yusuf E, Asmani F. Phytochemical screening and antibacterial activity of five Malaysian medicinal plants. British Journal of Pharmaceutical Research. 2014;4(17):2019-32.

6. Jiyauddin K, Zulhabri O, Aishah UAM, Rasha S, Hamid K, Qamar M, et al. Evaluation of antioxidant and antimicrobial activity of Artocarpus altilis against human pathogens. UK Journal of Pharmaceutical and Bioscience. 2014;2(4):10-4.

7. Tang YK, Rahman MA, Zajmi A. In vitro antioxidant and antibacterial activities of leaf and branch extracts of Morinsindica L. Journal of Management and Science. 2018;16(1):8-13.

8. Shalan N, Mustapha NM, Mohamed S. Morinda citrifolia leaf enhanced perfor- 
mance by improving angiogenesis, mitochondrial biogenesis, antioxidant, antiinflammatory and stress responses. Food Chemistry. 2016;212:443-52.

9. Calzuola I, Gianfranceschi GL, Marsili V. Comparative activity of antioxidants from wheat sprouts, Morinda citrifolia, fermented papaya and white tea. International Journal Food Science and Nutrition. 2006;57(3-4):168-77.

10. Takashima J, Ikeda Y, Komiyama K, Hayashi M, Kishida A, Ohsaki A. New constituents from the leaves of Morinda citrifolia. Chemical and Pharmaceutical Bulletin. 2007;55(2):343-5.

11. Prashant T, Kumar B, Kaur M, Kaur G, Kaur H. Phytochemical screening and extraction: A review. Internationale Pharmaceutica Sciencia. 2011;1(1):98-106.

12. Saad R, Aqil M, Yusuf E, Asmani F. Chromatopraphical fraction guided by antioxidant activity of Morinda citrifolia. International Journal of Pharmacy and Analytical Research. 2014;3(3):241-8.

13. Ramos S. Effects of dietary flavonoids on apoptotic pathways related to cancer chemoprevention. The Journal of Nutritional Biochemistry. 2007;18(7):427-42

14. Awad AB. Phytosterols reduce in vitro metastatic ability of MDA-MB-231 human breast cancer cells. Nutrition and Cancer. 2001;40(2):157-64.

15. Singh DR, Singh S, Banu, VS. Phyto-nutrient diversity in Morinda citrifolia L. genotypes of Andaman Islands, India. Journal of Hematology and Blood Disorders. 2017;3(1):103.

16. Adnan NE, Mohd Nasuha NA, Abdullah Z, Choo YM, Tajuddin HA. Isolation and photophysical properties of $\mathrm{Di}$ - and Tri-substituted natural anthraquinones from Malaysian Morinda citrifolia. Sains Malaysiana. 2018;47(5):903-6.

17. Beh HK, Seow LJ, Asmawi MZ, Abdul Majid AMS, Murugaiyah V, Ismail N, et. al. Anti-angiogenic activity of Morinda citrifolia extracts and its chemical constituents. Natural Product Research. 2012;26(16):1492-7.

18. Piaru SP, Mahmud R, Abdul MAMS, Daoud Z, Nassar M. Antioxidant and antiangiogenic activities of the essential oils of Myristica fragrans and Morinda citrifolia. Asian Pacific Journal of Tropical Medicine. 2012;5(4):294-8.

19. Shariq B, Zulhabri O, Hamid K, Sundus B, Mehwish H, Sakina R, et al. Evaluation of anti-atherosclerotic activity of virgin coconut oil in male Wistar rats against high lipid and high carbohydrate diet induced atherosclerosis. UK Journal of Pharmaceutical and Bioscience. 2015;3(2):10-4.

\section{GRAPHICAL ABSTRACT}

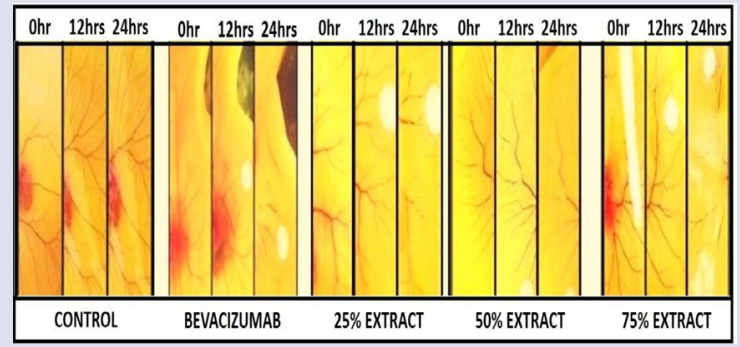

\section{SUMMARY}

- This study aims to investigate the anti-angiogenic properties of Morinda citrifolia. $L$ leaves extracts using Chicken Chorioallantoic Membrane (CAM) assay. The Fertile White Leghorn eggs were divided into five groups which were control, Bevacizumab drug and treatment groups with $25 \%, 50 \%$ and $75 \%$ of Morinda citrifolia. L leaves extracts respectively. Results have shown significant differences $(P<0.05)$ in the reduction of the blood vessel between each group at $24 \mathrm{~h}$ post-treatment. The group with $75 \%$ extracts showed $37.1 \%$ reductions of blood vessel compared to groups $50 \%$ and $25 \%$ extracts which showed $4 \%$ and $12.8 \%$ respectively. As a conclusion Morinda citrifolia. L leaves extracts consist of the phytochemical compounds that have the ability to inhibit the angiogenesis.

Cite this article: Othman Z, Khalep HRH, Abidin AZ, Hassan H, Fattepur S. The Anti-Angiogenic Properties of Morinda citrifolia L. (Mengkudu) Leaves using Chicken Chorioallantoic Membrane (CAM) Assay. Pharmacog J. 2019;11(1):12-5. 